\title{
Paying for Performance: The Education Impacts of a Community College Scholarship Program for Low-income Adults
}

\author{
Lisa Barrow \\ lbarrow@frbchi.org \\ Federal Reserve Bank of Chicago \\ Lashawn Richburg-Hayes \\ Lashawn.Richburg-Hayes2@mdrc.org \\ MDRC \\ Cecilia Elena Rouse \\ rouse@princeton.edu \\ Princeton University \\ Thomas Brock \\ Thomas.Brock@mdrc.org \\ MDRC
}

December 2010

REVISED: February 2012

\begin{abstract}
We thank Jonathan Davis, Elizabeth Debraggio, Laurien Gilbert, Shani Schechter, and Zach Seeskin for expert research assistance and Colleen Sommo and Jed Teres for extensive help in understanding the data. Joshua Angrist, Jonas Fisher, Luojia Hu, David Lee, Bruce Meyer, Derek Neal, Chris Taber, and seminar participants at the American Education Finance Association meetings, Federal Reserve Bank of Chicago, Harris School of Public Policy Studies, and MIT provided helpful conversations and comments. We also thank Louis Jacobson and Christine Mokher for graciously providing additional estimates on the value of college courses. The data used in this paper are derived from data files made available by MDRC. The authors remain solely responsible for how the data have been used or interpreted. Any views expressed in this paper do not necessarily reflect those of the Federal Reserve Bank of Chicago or the Federal Reserve System. Any errors are ours.
\end{abstract}




\title{
Paying for Performance: The Education Impacts of a Community College Scholarship Program for Low-income Adults
}

\begin{abstract}
We evaluate the effect of performance-based incentive programs on educational outcomes for community college students from a random assignment experiment at three campuses. Incentive payments over two semesters were tied to meeting two conditions-enrolling at least half time and maintaining a " $\mathrm{C}$ " or better grade point average. Eligibility increased the likelihood of enrolling in the second semester after random assignment and total number of credits earned. Over two years, program group students completed nearly 40 percent more credits. We find little evidence that program eligibility changed types of courses taken but some evidence of increased academic performance and effort.
\end{abstract}




\section{Introduction}

While the total (monetary and nonmonetary) benefits of attending a two- or four-year college are seemingly quite high, less than 60 percent of the population 25 to 35 years old reports having any college experience (Crissey 2009). Even among those who begin college, many have not completed any degree six years after their initial enrollment. This is particularly true at twoyear colleges which enroll 48 percent of all first-time, first-year college students (Berkner and Choy 2008). ${ }^{1}$ Six years after first enrollment, only 14 percent of students beginning at community colleges have completed an associate’s degree, and only 12 percent have completed a bachelor's degree. Nearly one-half have no degree and are no longer enrolled in school. ${ }^{2}$ As a result, many researchers and policy-makers have questioned whether there are policies that can increase enrollment persistence and completion rates at the college level. This paper examines one such policy—performance-based scholarships—-focused on improving academic success and persistence at community colleges.

Recently, there has been much interest in the ability of incentive awards and scholarships to improve student outcomes. In this paper, we explore whether a performance-based scholarship combined with counseling services affected the educational outcomes of low-income community college students (who were also parents). Students were randomly assigned to treatment and control groups. The treatment group was eligible to receive scholarship payments over two semesters for meeting certain benchmarks during the semester and also had access to supplemental counseling services. These were in addition to the standard financial aid and

\footnotetext{
${ }^{1}$ Relative to the typical four-year institution, community colleges lower the costs of investing in a college education: their open enrollment policies enable students who lack full preparation to invest in a college education, while their relatively low tuition and fees make college more affordable to all students.

${ }^{2}$ In comparison, 22 percent of students who begin in a public four-year institution and 19 percent of students who begin in a private (not-for-profit) four-year institution have no degree and are no longer enrolled in school 6 years after first enrollment (Radford, et al., 2010).
} 
counseling services available to control group students. We find that eligibility for the performance-based scholarship increased persistence by increasing enrollment probability in the second semester after random assignment. ${ }^{3}$ After two years, program group students earned 3.7 credit hours more than the control group students, an advantage of 37 percent. We also find some evidence that the program may have affected academic performance and effort.

Our results are consistent with related studies that have also found positive effects of performance-based incentives on education outcomes in different settings. At the college level, Angrist, Lang, and Oreopoulos (2009) provide some evidence that incentive scholarships, particularly combined with counseling services, may increase academic achievement among female, first-year students at 4-year colleges and that these effects may persist into their second year. At the secondary school level, Angrist and Lavy (2009) find in Israel that cash rewards for high school (Bagrut) certification and intermediate milestones (for example, taking component tests) increased certification rates among girls by roughly 10 percentage points. They also find some evidence that the incentive awards increased the likelihood of subsequent post-secondary school enrollment. Similarly, Jackson (2010a) finds that the Advanced Placement Incentive Program (APIP) in Texas - which rewards students (and teachers) for AP courses and exam scores-increased the share of students taking AP or International Baccalaureate (IB) exams. He also finds some evidence that the APIP increased the shares of students scoring above 1100 on the SAT Reasoning Test or 24 on the ACT Test, and later evidence (see Jackson 2010b) of impacts on college matriculation, persistence, and grades. Finally, in a U.S. experiment at the elementary and $9^{\text {th }}$ grade levels Fryer (2010) finds that financial incentives rewarding students for education inputs such as reading books, attending school, and turning in homework increased

\footnotetext{
${ }^{3}$ Early results from this study were reported in Brock and Richburg-Hayes (2006).
} 
test score achievement. In contrast, he finds that rewarding students for education outcomes such as grades and test scores led to no improvement in achievement test scores.

This paper is also related to college-level studies looking at merit scholarships and student aid, more generally. The most compelling evidence on the impact of tuition (and fees) suggests that students who receive greater grant aid are more likely to enroll in college and to persist, with larger impacts among two-year college students than four-year college students (see, e.g., Rouse 1994, Kane 1999, Dynarski 2003, 2000, 2008). Further, Scott-Clayton (2009) finds that a merit scholarship combined with performance incentives tied to grades and credits earned (the West Virginia PROMISE program) increases credits earned and the four-year BA completion rate.

We next discuss a theoretical framework for thinking about educational persistence and the role of incentive scholarships followed by a description of the intervention studied in section III. In section IV, we describe the data and present sample characteristics of program participants in comparison to community college students more generally. The estimation strategy and results are presented in Section V, and Section VI concludes.

\section{Theoretical framework}

\section{A. Persistence and Effort}

Following the model outlined by Becker (1967), economists typically hypothesize that students continue their education until the marginal cost outweighs the marginal benefit. Suppose that student $i$ 's grade point average (GPA) depends on ability $a_{i}$, effort $e_{i}$, and some random noise $\varepsilon_{i}$ as follows:

$$
g_{i}=e_{i}+a_{i}+\varepsilon_{i}
$$


Let $\varepsilon$ be distributed, $\mathrm{F}(\varepsilon)$, with density $\mathrm{f}(\varepsilon)$, and let $\mathrm{c}(e)$ reflect the cost of effort. Assume $c^{\prime}(e)>0$ and $c^{\prime \prime}(e)>0$. Further assume there is a payoff $W$ for achieving a minimum GPA $\bar{g}$ with a payoff of zero otherwise. ${ }^{4}$ Assuming students maximize utility by maximizing the net expected benefit of effort, the student's maximization problem is as follows:

$$
\max _{e}\left\{\left[1-F\left(\bar{g}-e_{i}-a_{i}\right)\right] \cdot W-c\left(e_{i}\right)\right\} \text { s.t. } e_{i} \geq 0
$$

Assuming the second order conditions are satisfied, the optimal value of effort, $e_{i}^{*}$, is characterized by the first-order condition:

$$
c^{\prime}\left(e_{i}^{*}\right) \geq f\left(\bar{g}-e_{i}^{*}-a_{i}\right) \cdot W
$$

Thus, a student may not enroll or continue in college because the marginal benefit is relatively low and/or because the costs are relatively high. The research evidence on whether the benefit of each additional year (or credit) is lower for dropouts than for students who stay in school is inconclusive (Barrow and Rouse, 2006), but there are many reasons to think that the costs, broadly construed, may differ across students.

B. Policy intervention and performance-based scholarships

There seems to be agreement that at least some of the dropout is not optimal and many policy experiments aim to increase educational attainment and persistence. Traditional needbased and merit-based scholarships provide an incentive to enroll in college, such as a reward payment for registration, effectively lowering the costs of enrolling in college because they are paid regardless of whether the student passes her classes. Performance-based scholarships (PBSs) generally try to improve student outcomes by increasing the immediate financial benefits from school. For example, payments may be contingent on meeting benchmark performance

\footnotetext{
${ }^{4}$ Alternatively, one could think about there being a payoff to each course completed with a minimum grade level. We also abstract from the possibility of a higher payoff to achieving grades above the minimum threshold.
} 
goals such as minimum GPAs. Thus the incentives can be thought of as increasing the immediate financial rewards to effort. Because a PBS provides more immediate financial rewards to effort, we would expect PBS eligible students to allocate more time to educationally productive activities such as studying which should in turn translate into greater educational attainment. ${ }^{5}$

If the density $f()$ in equation (3) is roughly normally distributed with small values in the tails, then whether and by how much a performance incentive changes an individual student's effort will depend on ability and the marginal cost of effort. For a high ability student, increasing the payoff $W$ will have little effect on her effort because she will essentially be able to meet the minimum GPA requirement on ability with no effort, i.e. ability alone puts her in the right tail of the density. Similarly, really low ability will put a student in the left tail of the distribution and an increase in $W$ will have little effect on her effort because the probability of meeting the minimum GPA requirement even with high levels of effort is so low and effort is costly. For students in the middle range of ability, the performance incentive will cause them to increase effort in order to increase the probability of meeting the minimum GPA requirement. On the cost side (all else equal) we would expect to see students facing a higher marginal cost of effort to have a smaller change in effort in response to changes in the payoff $W$ than students facing a lower marginal cost of effort. ${ }^{6}$

\footnotetext{
5 The incentive literature makes clear that to be effective, pay for performance and other incentive-based schemes must be clear and with tangible consequences or rewards (e.g., Milkovich and Newman, 2002). As a result, the structure of performance-based scholarships is more likely to generate changes in behavior than are others, such as Pell Grants, which have less clear benchmarks or have delayed consequences and rewards. For example Pell Grants require that students make "satisfactory academic progress" for continued eligibility, but it does not affect a student's financial aid during the semester in question. Further, both the definition of "satisfactory academic progress" and the consequences of falling behind academically for Pell eligibility are determined at the institutional level meaning that the incentives are likely less evident to a student than an incentive structure similar to that in the program analyzed in this paper.

${ }^{6}$ We have attempted to test for such implications of the model empirically by interacting the treatment effect with prior background variables such as whether or not the individual had already obtained an advanced degree or certificate, dependency status, and the presence of a child under the age of six. While the signs of some of the coefficient estimates were consistent with the model, the estimates were generally indistinguishable from zero. These results are available from the authors on request.
} 
While the intention of a performance-based scholarship is to increase student effort in educationally productive ways, there may be unintended consequences as well. Indeed, Cornwell, Lee, and Mustard (2005) find that the Georgia HOPE scholarship which had grade incentives but not credit incentives reduced the likelihood that students registered for a full credit load and increased the likelihood that students withdrew from courses presumably to increase the probability that they met the minimum GPA benchmark.

\section{The Opening Doors Scholarship and Counseling Program}

The data analyzed were collected as part of the Opening Doors Louisiana (ODLA) study conducted by MDRC between 2004 and 2005 as part of a larger, multiple site demonstration project. The Opening Doors demonstration was a longitudinal study that addressed two problems facing community colleges: 1) high rates of attrition, especially by low-income students; and 2) a dearth of reliable evidence on how to help students persist in community college to achieve long-term academic and labor market success.

The ODLA study was implemented at three community college campuses in the New Orleans area -- Delgado Community College (DCC) (the City Park and West Bank Campuses) and Louisiana Technical College (LTC)-West Jefferson campus -- and tested the effectiveness of an intervention that included a scholarship with both an incentive-based component and one more similar to traditional merit or need-based scholarships and enhanced counseling services. The study targeted low-income parents who were primarily first-term students at the college although some continuing students ready to move from remedial/developmental-level courses to college-level courses were also accepted into the program. To be eligible for the study, students had to be: willing to attend school at least half-time; 18 to 34 years old; the parent of at least one 
dependent child under 19 years old; and have family income below 200 percent of the federal poverty line. In addition, students had to have earned a high school diploma, a General Educational Development (GED) certificate, or a passing score on a college entrance examination, but they could not already have a degree or occupational certificate from an accredited college or university. These requirements meant that the eligible population was disproportionately female and poor. See Richburg-Hayes et al. (2009) for more details.

\section{A. Recruitment and random assignment}

Students were recruited on campus over four consecutive semesters (including summer) from spring 2004 to spring 2005 with a sample goal of 1000 students. Once program staff determined eligibility for the study, students who agreed to participate provided baseline demographic information, completed a survey on health information, and were randomly assigned by MDRC to the program or control group. Everyone completing the random assignment process received a \$20 gift card. In Table 1 we present information on the number of students in each cohort on each campus. In total 1019 students were recruited; 505 were randomly assigned to the program-eligible group and 514 were assigned to the control group. Not surprisingly, recruitment was most successful for the fall cohort; the spring 2005 cohort is unusually small simply because recruitment stopped once recruiters determined that the target sample would be met. Delgado is the larger of the two institutions, and the City Park campus is larger than the West Bank campus generating differences in sample sizes across sites.

B. Scholarship and incentives 
The ODLA offered program-eligible students a \$1000 scholarship for each of two semesters (maximum \$2000 total) as a supplement to the Pell Grant and other financial aid programs. The maximum scholarship payment was generous in that it exceeded full-time tuition and fees at the two colleges. In 2004-05, tuition and fees were roughly $\$ 1500$ per year for a fulltime student at Delgado and $\$ 900$ per year for a full-time student at LTC. That said, these students typically had a fairly large amount of unmet need that would have to be met by working and/or taking out student loans. For example, the total cost of attending Delgado (tuition, fees, books, and room and board) was $\$ 12,126$ per year in $2004-05$. With a full Pell grant of $\$ 4050$, a student would have unmet need of more than $\$ 8000$ (See Richburg-Hayes et al. (2009).).

Scholarship payment was structured such that a student received $\$ 250$ at the start of the semester if she enrolled at least half-time (six or more credit hours), she received $\$ 250$ after midterms if she stayed enrolled at least half-time and maintained a C-average or better, and she received $\$ 500$ after the end of the semester if she stayed enrolled at least half-time and maintained a C-average or better for the semester. Receiving payment at the end of the semester was not contingent on receiving the midterm payment so students with less than a C-average after midterms could raise their grades to qualify for the $\$ 500$ payment at the end of the semester. Similarly, failure to qualify for payment in the first semester did not disqualify the student from payments in the second semester.

In Table 2 we present information on the number and percentage of program and control group students receiving scholarship payments, the distribution of the size of payments received, and total dollar value of the payments received in the first and second semester after random assignment. We also present similar information cumulatively for the first through seventh 
semester after random assignment. ${ }^{7}$ Eighty-four percent of program group students received one or more scholarship payments in the first semester, 62 percent received one or more scholarship payments in the second semester, and nearly 90 percent of program students received at least one scholarship payment over the first through seventh semester after random assignment. Roughly 30 percent received the full $\$ 2000$ scholarship over the 7 semesters after random assignment, and nearly 60 percent received $\$ 1000$ in at least one semester. In each of the first two semesters, the average scholarship payment among recipients in the program group was around $\$ 750$. Overall program group students received total scholarship payments averaging $\$ 1133$. While we cannot measure whether program group students were mistakenly told they were not part of the program, we can check the number of control group students who received scholarship payments. Only 3 control group students received any payment so contamination seems minimal.

When asked how they used the scholarship money, 66\% of respondents reported using it for books and school supplies and about $45 \%$ reported using it to help pay bills, buy gas or bus fare, and pay for child care costs. Asked for the main use of the scholarship money, $46 \%$ of recipients cited to purchase books and school supplies (Richburg-Hayes, et al. 2009). These uses are consistent with (successful) participants attempting to use the funds to help with educational expenses or basic household maintenance.

\footnotetext{
${ }^{7}$ With the exception of the spring 2005 cohort, students did not have to enroll in consecutive semesters to take full advantage of the offer. Because the program ended in August 2005, students from the spring 2005 cohort needed to attend both the spring and summer 2005 semesters to receive the maximum benefit; whereas, students from the spring 2004 cohort, for example, had five semesters over which they could take advantage of the program. The incentive structure was also modified somewhat for the summer semesters at Delgado during which classes met half as many months but for twice as many hours each session. For the summer semesters at Delgado, program students were eligible for $\$ 500$ at the beginning of the semester after registering at least half-time and $\$ 500$ at the end of the semester if they stayed enrolled at least half-time and received a C-average or better. Additionally, for the final semester of the program (summer 2005), Delgado also allowed students a half scholarship of \$500 total if they enrolled in a single, three-hour credit course.
} 


\section{Enhanced counseling}

MDRC had originally hoped that the counseling component would result in counselors getting to know students on a personal level and taking an active role in non-academic advising. While this may have been true for some counselors, MDRC's study of the program implementation showed that the counselors more typically served as program monitors: checking up on students' enrollment status, verifying grade benchmarks were achieved, meeting with students to explain rules, and handing out scholarship checks (Richburg-Hayes, et al. 2009).

\section{Data sources and sample characteristics}

All data used in this study were compiled by MDRC and come from several sources. From the baseline data collected before random assignment we use basic demographic characteristics. Scholarship data provide information about the timing and size of the Opening Doors Scholarship payments. Transcript data for at least 7 semesters following random assignment were collected from Delgado and LTC and contain data on registration, credits earned, grades, and withdrawals. Notably, the transcript data only cover semesters in attendance at DCC and LTC. However, MDRC also matched the ODLA participants to National Student Clearinghouse (the Clearinghouse) data. The Clearinghouse data provide enrollment, degree, and certificate data for all students matched to any Clearinghouse reporting institution. That said, the Clearinghouse coverage is not complete due to non-reporting institutions and students who opt out of having their data included. Importantly, LTC did not report to the Clearinghouse.

Finally, MDRC attempted to survey all participants with a follow-up survey roughly 12 months after random assignment; however, the follow-up survey was interrupted as a result of 
Hurricane Katrina on August 29, 2005. Ultimately 79\% of the original participants completed a follow-up survey. Nearly half the sample (492 respondents) was surveyed before Hurricane Katrina, an average of 13 months after random assignment. The remaining 402 respondents were surveyed after Hurricane Katrina, an average of 21 months after random assignment. From these follow-up data we use measures of the participants' educational experiences, namely reports on time spent on campus and studying.

Table 3 presents selected mean baseline characteristics for study participants at the time of random assignment. For comparison, we also present mean characteristics for a nationally representative sample of first-time, two-year public college students between the ages of 17 and 34 from the U.S. Department of Education's 2004 Beginning Postsecondary Survey (BPS) and for the subset of these students from Louisiana. ${ }^{8}$ Compared with community college students generally or the subset of students in Louisiana, the eligibility requirements mean that study participants were nearly 5 years older than typical first-time community college students, more likely to be female (92 percent versus 57 percent of Louisiana community college students), more likely to be black (85 percent compared with 43 percent of Louisiana community college students), more likely to have children (all participants versus 22 percent), and less likely to be financially dependent on their parents (17 percent of study participants compared with 73 percent of first-time community college students). Study participants were also less well-prepared academically: 17 percent of study participants had a GED rather than a high school diploma compared with only 8 percent of community college students in the nation or Louisiana.

As another way to understand the characteristics of the study participants compared with community college students more generally, we estimated the likelihood that a community

\footnotetext{
${ }^{8}$ The BPS is a longitudinal study that follows students who are enrolled in a postsecondary institution for the first time. The most recent BPS cohort consists of approximately 19,000 students who were first interviewed in 2004 as part of the National Postsecondary Student Aid Study; we use data from 2004.
} 
college student in the BPS would complete an associate's degree or higher and their number of years of schooling within six years. We then used the coefficient estimates to predict educational attainment for each sample. Not surprisingly, when evaluated at the mean of the individual characteristics, we estimate that the students in the Opening Doors sample are about 3.5 percentage points less likely than students in the BPS to complete at least an associate's degree, and they are predicted to complete 0.18 fewer years of schooling within six years of initial enrollment. In sum, the study participants were generally more likely to possess characteristics that are associated with an increased risk of failing to complete a college degree than the typical community college student in Louisiana or the nation.

We present mean characteristics by random assignment status in the first two columns of Table 4. In each case the means are adjusted for randomization pool fixed effects reflecting the campus and cohort of study recruitment. In the third column we present the p-value for the test that the adjusted mean for students assigned to the program group is equal to the adjusted mean for the students assigned to the control group. Two characteristics-sex and race-are statistically different between the treatment and control groups at the 10 percent level of significance. At the 5 percent level of statistical significance, the control group is more likely to report race as “other” and more likely to report living in section 8 or public housing. However, jointly the baseline characteristics do not predict treatment status $(\mathrm{p}$-value on the F-test $=0.19){ }^{9}$

\section{Estimation and Results}

\footnotetext{
9 Similarly combining baseline characteristics into an "outcome" index we find no statistically significant differences by treatment status ( $\mathrm{p}$-value $=0.532)$. Results for all estimates including baseline controls are similar and available from the authors on request. Notably, the precision of our estimates is not improved by including baseline controls.
} 
Below we present estimates of the effect of program eligibility on a variety of outcomes. We model each outcome $Y$ for individual $i$ as follows:

$$
Y_{i}=\alpha+\beta T_{i}+X_{i} \Theta+p_{i} \gamma+v_{i}
$$

where $T_{i}$ is a treatment status indicator for individual $i$ being eligible for the program scholarship and enhanced counseling, $X_{i}$ is a vector of baseline characteristics (which may or may not be included), $p_{i}$ is a vector of indicators for the student's cohort and campus of random assignment, $v_{i}$ is the error term, and $\alpha, \beta, \Theta$, and $\gamma$ are parameters to be estimated with $\beta$ representing the average effect on outcome $Y$ of being randomly assigned to be eligible for the scholarship and enhanced counseling services.

A. Program effects at the participating colleges

In Table 5 we present estimates of the effect of program eligibility on various short-run outcomes measured by transcript data provided by DCC and LTC. In column (1) we provide outcome means for the control group participants. The program effect estimates with standard errors in column (2) are estimated including controls for randomization pool fixed effects but no other baseline characteristics. Because we provide estimates for a number of related outcomes, in column (3) we present p-values adjusted for multiple testing. ${ }^{10}$

The top panel of Table 5 includes transcript outcome measures for the first semester after random assignment. We find that program-eligible students were 5 percentage points more likely to be enrolled in any course at the intervention institution after the end of the drop/add period; however, the impact does not remain statistically significant at the 5 percent level after adjusting

\footnotetext{
${ }^{10}$ We calculate adjusted p-values using bootstrap resampling of vectors in a stepdown fashion following Westfall and Young (1993). In Table 5 we adjust the p-values considering the group of outcomes within semester.
} 
for multiple testing. ${ }^{11}$ We find that program-eligible students attempted and earned more credits as well. In fact, program group students earned roughly 1.2 credits more than control group students in the first semester (a difference that is significant at the $5 \%$ level once adjusting for multiple testing). Notably, this impact is mostly explained by gains in regular credits attempted and earned (rather than remedial credits). In order to receive any scholarship payment, students were required to register for at least 6 credits. In results not reported (here but available on request), while program eligible students were less likely to be enrolled less than half time (1 to 5 credits) and more likely to be enrolled either part-time (6 to 11 credits) or full-time (a minimum of 12 credits), the differences are not statistically significant. Overall, if we create an index of the first semester outcomes as in Anderson (2008) we find a statistically significant difference between treatment and control students $(\mathrm{p}$-value $=0.022){ }^{12}$

We present program effect estimates for outcomes in the second semester after random assignment in the bottom panel of Table 5. Here we find that program eligibility increased persistence: program-eligible students were 15 percentage points more likely to have enrolled in any course after the second semester drop/add period with an adjusted p-value $<0.0001$. This strong effect on enrollment generates several other statistically significant differences because, for example, one cannot earn credits without enrolling. Program group students attempted 1.2 credits more than control group students and by the end of the second semester had earned 1.1 more credit hours, 40 percent more than the control group students.

Such increases in credit accumulation can be decomposed into two impacts: an impact of the program on enrollment and an impact of the program on credits attempted/earned conditional

\footnotetext{
${ }^{11}$ The "drop/add" period is the period at the beginning of the semester during which students may elect to add or drop a course for which they had initially registered. It typically ended 5 days after the start of the semester.

${ }^{12}$ The index includes all semester 1 outcomes presented in Table 5 as well as the indicators for full-time and parttime status discussed in the text. In creating these indices, we weighted by the inverse of the covariance matrix.
} 
on enrollment. Following Lavy (2009), one can write the average number of credits earned or attempted by students in group $i$ as:

$$
P_{i} Y_{i}^{1}+\left(1-P_{i}\right) Y_{i}^{0}
$$

where $P_{i}$ is the share of students registering that semester, $Y_{i}^{1}$ is the number of credits earned or attempted by students registering and $Y_{i}^{0}$ is the number of credits earned or attempted by students not registering. By assumption, credits attempted and credits earned equal zero among students who do not register so the average expected number of credits earned/attempted for group $i$ is $P_{i} Y_{i}{ }^{1}$. The average treatment effect is $P_{1} Y_{1}{ }^{1}-P_{0} Y_{0}{ }^{l}$ where group 1 is the program group and group 0 is the control group. The average treatment effect can be rewritten as $\left(P_{1}-P_{0}\right) Y_{1}{ }^{1}+P_{0}\left(Y_{1}{ }^{1}\right.$ $Y_{0}{ }^{1}$ ). The first term represents the portion of the unconditional increase that is due to the impact of the program on the likelihood of enrollment while the second represents the increase in credits attempted or earned conditional on enrollment. ${ }^{13}$ We estimate that all of the unconditional increase in credits attempted in the second semester is due to an increase in the likelihood of enrollment while for credits earned in the second semester, 27 percent of the increase is due to the increase in credits earned conditional on enrollment. ${ }^{14}$

Once again, program group students do not seem to be shifting credits disproportionately toward remedial courses. We also find (in results not reported here) that program group students were 12.2 percentage points more likely to enroll part-time, but there is no statistical difference

\footnotetext{
${ }^{13}$ To do this calculation, we estimate the ATE components separately by randomization pool. Specifically, we calculate the weighted average of each component for the 11 pools where the weights are the share of the students in each pool. To estimate the share of the impact resulting from enrollment, we divide the weighted average of this component by the weighted average of the ATE.

${ }^{14}$ In the first semester when the program effect on registration is smaller, we estimate that 86 percent of the increase in credits attempted is due to the increased enrollment while for credits earned 71 percent of the increase is due to the increase in credits earned conditional on enrollment.
} 
in the percentage enrolled full-time or less than half time. Once again, an index of second semester outcomes is statistically different between treatment and control group students with a p-value $<0.001 .^{15}$

B. Longer-run outcomes and effects on enrollment at "all” institutions

In order to consider longer-run outcomes for program and control group students, we focus on the first two cohorts of students for whom we observe the greatest number of semesters of potential study both before and after Hurricane Katrina. ${ }^{16}$ Limiting the sample to these first two cohorts, in the first column of Table 6 we present estimates for longer run outcomes based on transcript data. Outcomes related to enrollment are presented in the top panel while outcomes related to credits earned are presented in the bottom panel. During the first year after random assignment, a student could have enrolled for up to 3 semesters and earned at least 36 credits if she had enrolled full-time (12 or more credits) in each semester. While program group students were (statistically) no more likely to be enrolled in any course in the first semester after random assignment, they were 18 percentage points more likely to be enrolled in the second semester and nearly 12 percentage points more likely to be enrolled in the third semester. Cumulatively the program students were enrolled for 0.35 more semesters than the control group at the intervention campus in the first year. In the second year after random assignment, we find that program students had enrolled for 0.13 more semesters than the control group students and that cumulatively after two years the program group had enrolled for nearly 0.5 more semesters.

\footnotetext{
${ }^{15}$ The index includes all semester 2 outcomes reported in Table 5 as well as indictors for full-time and part-time enrollment.

${ }^{16}$ Program impact estimates for outcomes presented in Table 5 are quite similar if we limit the sample to the first two cohorts of students. These results are available from the authors on request.
} 
In the bottom panel, we present results on total credits earned. After the first year, students in the program group had earned 3.3 more credits (or roughly one-quarter of one fulltime semester's worth of credits) and nearly 45 percent greater than the number of credits earned by the control group. In the second year after random assignment (semesters 4, 5, and 6), we find no statistically significant difference in the total number of credits earned; however, the positive point estimate indicates that control group students were not catching up to program group students over a longer time horizon. ${ }^{17}$ Two years after random assignment, program group students had enrolled nearly one-half of one semester more than control group students and earned an additional 3.7 credits.

While program eligibility increased persistence and the number of credits earned as shown above, these reflect outcomes at the intervention campus. Clearly control group students had less incentive to stay at the intervention campus if they decided that a different campus would be a better match. As a result, one might expect that our estimates of the program's impact are biased upward. In order to examine this possibility, we supplement our transcript data with those available from the National Student Clearinghouse in order to include education outcomes at other institutions. As mentioned in the data discussion, these Clearinghouse data are not ideal because not all institutions report to the Clearinghouse, and students may decline to have their information included. In particular, LTC does not report to the Clearinghouse. ${ }^{18}$ Therefore, we report results for all study participants as well as the sub-sample of participants who were

\footnotetext{
${ }^{17}$ In results not shown here, we estimate the impacts on the likelihood of enrollment in the $4^{\text {th }}, 5^{\text {th }}$, and $6^{\text {th }}$ semesters after random assignment separately. While the point estimates are positive (reinforcing the likelihood that the control group students were not catching up to the program group students), the magnitudes were not statistically significant at conventional levels. These results are available on request.

${ }^{18}$ MDRC was able to match nearly 80 percent of participants with a record in the Clearinghouse data. Of the participants not matched with a Clearinghouse record, 71 percent were from a cohort recruited at LTC.
} 
recruited on either of the DCC campuses. These results are presented in the remaining columns of Table 6 .

In column (2) of Table 6 we supplement the transcript data provided by the institutions with data from the Clearinghouse. The results are roughly similar to those presented in column (1) with the largest impacts in the percentage of students enrolled in any course in the second and third semesters after random assignment. Program-eligible students also enrolled for roughly one-third more semesters in the first year following random assignment.

Columns (3) and (4) limit the sample to students recruited at the Delgado campuses since Delgado reports to the Clearinghouse. Using Delgado transcript data, the estimated program effects are somewhat larger than the transcript data estimates presented in column (1) which include LTC recruits. Using Clearinghouse data for the Delgado campuses only, we find that program-eligible students were 18.8 percentage points more likely to enroll in the second semester and 15.2 percentage points more likely to enroll in the third semesters after random assignment. Over the first year, program-eligible students enrolled in 0.40 more semesters than control group students; over two years, program-eligible students enrolled in 0.52 more semesters than control group students.

Overall the Table 6 results suggest that the program increases enrollment persistence and educational attainment rather than simply encouraging program students to maintain enrollment and earn credits at a particular institution in the short run. If the scholarship served only to encourage program group students to stay at the intervention campus while control group students enrolled at other campuses, then we would have expected to see no difference between treatment and control students in second and third semester enrollments once we accounted for 
enrollment at all campuses reporting to the Clearinghouse. Indeed, including data on enrollment from the Clearinghouse data reduces the point estimate of the program effect on second semester enrollment by a small amount; however, the estimated program impact remains large and statistically significant. $^{19}$

C. Does program eligibility affect the types of courses taken?

One unintended consequence of the incentive-based scholarship may have been to affect the types of courses for which students registered. We have shown in Table 5 that program group students did not reduce the number of total credits attempted and program and control group students did not differ in the number of remedial credits attempted. However, program group students may have attempted to register for "easier” courses in order to increase the probability that they would be able to meet the minimum semester GPA of 2.0 to qualify for the mid-semester and end-of-semester scholarship payments. While we do not have direct information about the difficulty of different courses offered, we do have information about the "fields" of the courses taken and can assess whether program and control group students took different numbers of credits in different fields.

Jacobson, LaLonde, and Sullivan (2005) find that among displaced workers, earnings gains per credit are larger for quantitative or technically-oriented courses than for non-technical courses. Similarly, Jacobson and Mohker (2009) find that additional courses in health-related

\footnotetext{
${ }^{19}$ Ideally, we would also like to use these data to examine long run outcomes such as certificate and degree receipt. Unfortunately, because these students are not typically enrolled full-time and because we have Clearinghouse data only up through two years after random assignment, we observe very few students completing degree or certification requirements. Only 12 of the original Delgado students show up as having received a certificate or degree: 6 have received a certificate, 5 received an Associates' degree, and 1 received a Masters’ degree.
} 
fields are the most valuable followed by vocational/technical courses, professional courses, and courses in the science, technology, engineering, and mathematics (STEM) cluster. They find no statistically significant value of additional courses in social sciences or humanities. If we assume monetary returns to courses are higher for more difficult courses, we can infer whether the program induced students to take easier courses by looking at the estimated program effects on credits attempted by field. Shifts in course-taking away from health-related, vocational/technical, STEM, and professional courses toward courses in the social sciences and humanities would provide evidence the program may have induced students to take easier courses. ${ }^{20}$

We follow Jacobson and Mohker (2009) in assigning each course to one of eight categories-Health Related; Humanities; Professional; STEM; Social Sciences; Vocational/Technical; Remedial; or Other. See Appendix A for more detail. In column (1) of Table 7, we present the cumulative average number of credits attempted by field for the control group students in the first two semesters after random assignment. This ranges from 0.22 credits in the Vocational/Technical field to 4.17 credits in STEM courses (column (1)). We then use the (cumulative) number of credits attempted in each field as an outcome variable and present the program effect estimates for each field in column (2). If scholarship eligibility does not affect the fields of courses taken and those induced by the program to register take a similar distribution of classes to those who would have registered anyway, then we would expect to find increases in the number of credits attempted between treatment and control group students for all fields. As can be seen in column (2), all program effect estimates are positive, but only the program impact of 0.41 credits attempted in social sciences can be rejected at the 5 percent level

\footnotetext{
${ }^{20}$ We note, however, that this prediction is not entirely clean because changes in the pattern of course-taking may occur instead because those students induced by the program to enroll take courses in different fields than those who would have enrolled anyway.
} 
after adjusting for multiple testing, providing some evidence that the performance-based scholarship induced eligible students to register for easier courses, on average. ${ }^{21}$

The results are less clear, however, when we focus on the types of credits earned, the results of which are presented in columns (3) and (4). Average credits earned by field for the control group students are presented in column (3) and range from 0.16 credits in the vocational/technical field to 2.38 credits earned in STEM. In column (4) we present the associated program effect estimates. Once again we find that the program impact on credits earned is positive for each field. Further, program group students earn an additional 0.654 STEM credits (adjusted p-value $=0.018$ ) and 0.412 social science credits (adjusted p-value $=0.002$ ) than control group students; no other differences in credits earned by field are statistically different from zero at conventional levels after adjusting for multiple testing. While Social Sciences are likely to be "easier" classes as measured by the average earnings effect per course taken, by this same measure STEM classes are likely to be "harder" classes. Thus, we conclude that there is little evidence that the program resulted in students earning relatively more credits in “easier” courses as measured by their value in terms of future earnings. ${ }^{22}$

D. Does program eligibility increase academic performance and effort?

Clearly enrolling in school requires more educational effort than not enrolling. However, the fact that program eligibility increased the number of credits earned in the first semester after random assignment and that 27 percent of the increase in second semester credits earned is due

\footnotetext{
${ }^{21}$ If we simply categorize courses as "hard”-Health Related, Professional, STEM, and Vocational/Technical—or "easy"-Humanities, Social Sciences, Remedial, and Other-we find that the program effect on credits attempted is 0.81 credits for hard courses (adjusted p-value $=0.229$ ) and 0.93 credits for easy courses (adjusted p-value $=0.051$ ). Adjusted p-values are calculated taking into consideration all credits attempted and credits earned outcomes tested in Table 7 in addition to the aggregate easy and hard categories.

${ }^{22}$ Again if we simply categorize courses as hard or easy (see footnote 21) we find program effect estimates of 1.183 more hard credits and 1.124 more easy credits in the first two semesters after random assignment. Both are statistically different from zero after adjusting for multiple testing.
} 
to an increase in credits earned conditional on enrollment suggest that program eligibility may have had an impact on student effort for a student who would have enrolled regardless of scholarship eligibility. To look for evidence of a program effect on academic performance and effort more directly, we turn to estimates of the effect of program eligibility on course grades, term GPA, hours spent on campus, and hours spent studying.

Because not all courses result in a letter grade, we begin by simply looking at the distribution of course grades by treatment status. These are presented in Figures 1a and 1b, respectively, for the first and second semesters after random assignment. For each group the bars represent the percent of courses earning that grade. Looking at the letter grades for the first semester on the left hand side of figure 1a, we can see that students in the program group earn somewhat higher shares of grades “A,” "B,” and “C.” Specifically, 53 percent of courses taken by control group students resulted in a grade of $\mathrm{A}, \mathrm{B}$, or $\mathrm{C}$ compared with 62 percent of courses taken by students in the program group. In contrast, 14 percent of courses taken by students in the control group resulted in a grade of " $F$ " compared with 9.5 percent of courses taken by students in the program group. Looking at the "ungraded” course outcomes, nearly 21 percent of courses taken by control group students resulted in a withdrawal compared with 15 percent of courses taken by program group students. Indeed, a simple chi-squared test for independence of treatment status and course grade category has a p-value of 0.000 .

In the second semester of the program, the grade distributions look more similar although the distributions are still statistically different with the p-value on the chi-squared test for independence of treatment status and course grade category equal to 0.021 . Grades of A, B, and C are more common among courses taken by program group students (57 percent of course grades for program group students versus 51 percent of course grades for control group 
students). Courses taken by program group students are somewhat less likely to end up with a grade of $\mathrm{F}$ and less likely to end up as a withdrawal. ${ }^{23}$

The grade distributions in Figure 1, particularly for the first semester in which there is a smaller program effect on registration, suggest that indeed program eligibility improved students’ academic outcomes for both graded and ungraded course outcomes. MDRC calculated term GPAs from the transcript data for students who enrolled. Using indicators for "GPA greater than or equal to 2.0” and "no GPA,” we find that 58 percent of program group students earn a GPA of 2.0 or higher in the first semester compared to 47 percent of control group students, a difference that is statistically significant at the 1 percent level after adjusting for multiple testing. Program group students are 7.7 percentage points less likely to have no GPA with an adjusted pvalue of 0.11 . These differences are even larger in the second semester after random assignment because program eligibility has such a large effect on enrollment. Thus, we look at upper and lower bound estimates of the effect of program eligibility on term GPAs and other measures of effort based on survey responses using assumptions about selection.

In addition, the MDRC follow-up survey includes two questions that may be used to assess whether the program affected hours spent on campus and hours spent studying in the first and second semester. For the survey questions on hours spent on campus, the potential response categories are: none, 1 to 3,4 to 6,7 to 9,10 to 12 , and more than 12 . For the survey questions on hours spent studying, the potential response categories are: none, 1 to 3,4 to 6,7 to 9,10 to 12, 13 to 15,16 to 18 , and more than 18 hours. We convert the responses to continuous measures using the midpoint of the range and assigning 15 hours to respondents who report more than 12 hours per week on campus and 20 hours to respondents reporting more than 18 hours per

\footnotetext{
${ }^{23}$ Eleven percent of program group courses receive a grade of $\mathrm{F}$ and 22 percent ended up with a withdrawal. In comparison, 13 percent of control group courses ended up with a grade of $\mathrm{F}$ and 28 percent ended up with a withdrawal.
} 
week spent studying. ${ }^{24}$ Students who report not being enrolled in the intervention school that semester are assigned missing hours for both activities.

In Table 8, column (2) we present estimates of how program eligibility affected term GPA and effort ignoring the selection effect. Because program eligibility affects the probability that a student is enrolled in school, it also affects whether we observe GPA as well as our measures of effort—hours spent on campus and hours spent studying. Furthermore, observations on hours spent on campus and studying are limited to follow-up survey respondents. As a result, we follow the trimming strategy of Lee (2009) in estimating upper and lower bounds of treatment effects in the presence of sample selection. ${ }^{25,26}$ Namely, we trim the top or bottom “excess" share of observations from the treatment group (assuming treatment increased registration) and compare this trimmed mean to the control group mean in order to generate the lower and upper bound estimates of the effect of program eligibility on the outcome of interest.

These lower and upper bound estimates are presented in columns (3) and (4). Once again the mean of the outcome variable for the control group is presented in column (1). ${ }^{27}$ Ignoring selection, program eligibility raised first semester GPA by 0.18 points. The lower bound estimate

\footnotetext{
${ }^{24}$ We have also tried converting to continuous measures using the minimum or maximum of the range. The results for hours spent studying are quite similar to those using the midpoint assumption. For hours spent on campus, the lower bound estimates are also insensitive to the interpolation assumption. The upper bound estimates for the effect of the program on hours on campus are somewhat more sensitive to the assumption ranging from 0.31 to 0.70 hours in the first semester and ranging from 1.2 to 2.1 hours in the second semester.

${ }^{25}$ In our particular application, we trim the sample within randomization pool and then calculate the weighted mean of the separate estimates to get the overall estimates of the bounds.

${ }^{26}$ An alternative strategy is to assume that the students not enrolling would have had GPAs or hours of effort at the bottom of the distribution and then artificially censor the data and estimate Tobit regressions as in Angrist, Bettinger, and Kremer (2006). One could also make similar assumptions and estimate quantile regressions looking for treatment effects in the upper quantiles of the distributions. If we do the latter for GPA effects, we estimate a 0.13 grade point effect on GPA at the median in the first semester (median control group GPA=2.0) and no effect at the $75^{\text {th }}$ percentile (control group GPA=3.0). In the second semester we find no effect at the median (control group GPA of 0.0) and a 0.5 grade point effect on GPA at the $75^{\text {th }}$ percentile (control group GPA=2.29). Using the strategy of Angrist, Bettinger, and Kremer (2006) we generally get somewhat larger estimates although the estimates are sensitive to the choice of the artificial censoring points.

${ }^{27}$ If we control for student baseline characteristics for the outcomes presented in table 8, the treatment impacts are generally somewhat larger. For example, the estimated impact on first semester GPA rises to 0.24 with a standard error of 0.084. With the exception of hours spent on campus during the second semester, all other point estimates rise as well, but none are large enough to become statistically different from zero at conventional levels.
} 
is 0.04 points and the upper bound estimate is 0.38 points. The estimated impact on second semester GPA is smaller. Ignoring selection, program-eligible students had second semester GPAs that were 0.07 points higher than control group students. The lower bound estimated impact is -0.23 points, and the upper bound estimate is 0.36 points. $^{28}$

We assume that students' decisions about whether to enroll are driven by expectations about their own ability and that their expectations are correct on average (following the literature on dropout decisions and students' learning about their own ability to acquire human capital (See Stinebrickner and Stinebrickner (2009) and Trachter (2009).). As a result, we expect those induced by the program to enroll in college will, on average, be drawn from the bottom of the potential GPA distribution. This seems most compelling for the second semester after random assignment when most students have experienced a semester's worth of information about their own ability. Indeed conditional on registering for the first semester, first semester GPA is a significant predictor of registering second semester. This argument is somewhat less compelling for the first semester in which students presumably have received no new information about their ability to acquire human capital between being inducted into the study and enrolling in classes. As a result, 0.18 GPA points is our preferred estimate of the effect of program eligibility on student GPA in the first semester after random assignment. ${ }^{29}$

In the second semester after random assignment we believe the selection mechanism is operating such that those induced by the program to persist are coming from the bottom of the potential GPA distribution. As a result, our preferred estimate of the effect of program eligibility

\footnotetext{
${ }^{28}$ If the students induced by the program to earn a GPA earned the lowest GPAs among the program group students (in other words those induced to earn a GPA are the students who are trimmed from the program group) then the upper bound estimate of the effect of the program on GPA is the correct estimate of the effect of the program on GPA among students who would have earned a GPA in the absence of the program. Likewise, the lower bound estimate is the correct estimate if the students induced by the program to earn a GPA earned the highest GPAs among the program group students.

${ }^{29}$ If we instead assume all students with missing GPAs earned a 4.0, for example, the point estimate of the treatment effect is still positive.
} 
on term GPA in the second semester is between 0.07 and the upper bound estimate of 0.36 . In fact, if we impute second semester GPAs equal to first semester GPAs for students without a second semester GPA our estimate of the effect of program eligibility on second semester GPA equals 0.148 grade points with a standard error of $(0.092) .{ }^{30}$ Thus, we conclude that program eligibility induced or enabled students to put more effort toward their courses resulting in somewhat higher semester GPAs.

When we examine the first semester survey outcomes - hours spent on campus and hours spent studying — we find at most small effects of program eligibility on student effort on these margins, and the point estimates are not statistically different from zero. On average in the first semester, program-eligible students report having spent 0.07 more hours on campus and 0.12 more hours studying than students in the control group. The lower and upper bounds for the effect estimates are -0.15 and 0.44 for hours on campus and -0.6 and 0.6 for hours studying. Even if we think the upper bound estimates are the more realistic point estimates, program eligibility only increased studying and time on campus by about 30 minutes per week, roughly a 5 percent increase at the control group mean.

The estimated program impacts are larger for the second semester (as are the standard errors). On average, program eligible students report having spent 0.48 more hours on campus during the second semester and 0.68 more hours studying. Bounds on estimates for hours spent on campus and studying in the second semester are also larger and include negative values. That said, if we believe the upper bound estimates are more realistic, the estimated effects on hours spent on campus and studying are closer to 90 additional minutes per week for each, a 25 percent increase in time on campus at the control group mean and a 40 percent increase in time spent studying at the control group mean. While the likely direction of selection is difficult to assert,

\footnotetext{
${ }^{30}$ The point estimate is driven to zero if we impute a second semester GPA of 2.6 for all students missing GPAs.
} 
we believe the (positive) upper bound estimate is closer to the "truth" than the (negative) lower bound estimate. We draw this conclusion because empirically we find that first semester hours spent studying and on campus for control group students who enroll in both the first and second semester are higher than first semester hours spent on campus and studying for control group students who enroll in the first but not the second semester. As in theory the control group represents the counterfactual for the program group, this finding suggests that the program group students who were induced to enroll in the second semester as a result of the program come from the bottom of the distributions of hours studied and on campus as assumed in the calculation of the upper bound. As a result, we believe the results provide suggestive evidence that program eligibility had positive effects on hours spent on campus and studying during the second semester after random assignment and that the correct estimates are somewhere between the average and upper bound estimates.

\section{Conclusion}

We evaluate the effect of eligibility for a performance-based scholarship combined with counseling on education outcomes for low-income community college students who are also parents. We find evidence that the program increased student enrollment persistence and may have increased student effort. In particular, program eligibility increased enrollment by 15 to 18 percentage points relative to control group enrollment in the second semester after random assignment.

The program also may have affected academic performance and effort. First semester GPAs for program group students were 0.18 points higher than first semester GPAs for control 
group students. Assuming those induced to register in the second semester have lower GPAs on average, the program effect on GPA ranges between 0.07 and 0.36 GPA points. We find little evidence of a program effect on effort in the first semester as measured by time on campus or time spent studying. In the second semester, the upper bound estimates of the effect on time spent on campus and time spent studying are increases of 25 and 40 percent, respectively.

Over two years following random assignment, program group students earned 3.69 credits more than control group students. This translates into an additional 1.23 courses. Based on data from Florida, Jacobson and Mokher (2009) estimate that for a student beginning at a two-year college, each course completed is worth an additional \$121 per year in annual earnings, similar to estimates for displaced workers from Jacobson, LaLonde, and Sullivan (2005). ${ }^{31}$ Assuming this value stays constant in real terms, over 20 years 1.23 additional courses is worth \$2977. The cost of this gain in terms of scholarship payments was roughly $\$ 1100$ per pupil. As long as the administrative and other costs were less than $\$ 1877$ per pupil, which seems quite likely, the benefits of this program in terms of increased future income would seem to outweigh the cost of providing the scholarship.

That said, we have no longer-term information on wages in order to say that inducing these particular students to persist and earn more credits resulted in higher future earnings. The scholarship itself was fairly valuable in terms of hourly wages. At baseline, MDRC collected information on whether students were currently employed and if so, their current wage. Just over

\footnotetext{
${ }^{31}$ This estimate corresponds to the last two columns of the Results for Regression Models table in Appendix 4 of Jacobson and Mohker (2009) and is based on a regression of quarterly earnings on highest credential received (certificate, AA, BA, or graduate degree); total number of courses taken; and controls for educational preparation and performance, student demographics, experience, location, and school characteristics. For our purposes, the authors provided estimates that limited the sample to students beginning their post-secondary education at a twoyear college and do not include concentration indicators. If the sample is limited to students beginning at a four-year college, each course is worth \$216 per year. Estimates from Jacobson, LaLonde, and Sullivan (2005) (Table 3, column (6)) imply that women’s earnings increased \$101 per year (1995\$) per course (3 credits) completed which translates into a 13.1 percent return for one academic year's worth of credits (9 courses).
} 
50 percent of the study participants were currently employed at baseline (52 percent of the control group and 51 percent of the treatment group), and of those 86 percent were paid on an hourly basis. The average wage among those employed hourly was $\$ 7.32$ with a median wage of \$7.00. At $\$ 7.32$ per hour, a student would have to work 102.5 hours over the semester to earn $\$ 750$ or roughly 7 hours per week over a 15 week semester. Assuming students were planning to devote some hours to school without the PBS, for many an additional 4 or 5 hours of studying to meet the GPA benchmarks may have been a better paying job than their alternative.

This study leaves open several questions about how this program or any other performance-based scholarship may affect educational outcomes. Angrist, Lang, and Oreopoulos (2009) find some effects of a performance-based scholarship on academic achievement in a more traditional college setting, but these impacts are driven by female students. Given that the Opening Doors Louisiana participants are predominantly women, the question remains whether performance-based scholarships can improve academic outcomes for men. Furthermore, one would hope that performance-based scholarships would have an effect because they enable or encourage students to spend more time in educationally productive activities such as studying. Stinebrickner and Stinebrickner (2003) provide evidence that hours working while in school have a negative effect on academic performance. Therefore, scholarships for nontraditional students such as those in the Opening Doors study may enable students to decrease hours worked and increase time on educational activities and subsequently increase academic achievement. At the same time, such scholarships may have less desirable consequences. While we did not find much evidence that scholarship eligibility changed students' course-taking behavior, it is possible that performance-based scholarships may increase effort in ways that are not educationally productive such as cheating or harassing professors for better grades. 


\section{References}

Anderson, Michael L. (2008). "Multiple Inference and Gender Differences in the Effects of Early Intervention: A Reevaluation of the Abecedarian, Perry Preschool, and Early Training Projects,” Journal of the American Statistical Association 103:484, 1481-1495.

Angrist, Joshua, Eric Bettinger, and Michael Kremer (2006). "Long-Term Educational Consequences of Secondary School Vouchers: Evidence from Administrative Records in Colombia," The American Economic Review 96:3, 847-62.

Angrist, Joshua and Victor Lavy (2009). "The Effects of High Stakes High School Achievement Awards: Evidence from a Randomized Trial,” The American Economic Review 99:4, 1384-1414.

Angrist, Joshua, Daniel Lang, and Philip Oreopoulos (2009). "Incentives and Services for College Achievement: Evidence from a Randomized Trial," American Economic Journal: Applied Economics 1:1, 136-63.

Barrow, Lisa and Cecilia Elena Rouse (2006). U.S. Elementary and Secondary Schools: Equalizing Opportunity or Replicating Status Quo? Future of Children Journal, Vol. 16, No. 2, 2006, pp. 99-123.

Becker, Gary S., Human Capital and the Personal Distribution of Income: Ann Arbor, University of Michigan Press, 1967.

Berkner, Lutz, and Susan Choy (2008). Descriptive summary of 2003-04 Beginning Postsecondary Students: Three Years Later. (NCES 2008-174). Washington, DC: National Center for Education Statistics, Institute of Education Sciences, U.S. Department of Education.

Brock, Thomas and Lashawn Richburg-Hayes (2006). Paying for Persistence. Early Results of a Louisiana Scholarship Program for Low-Income Parents Attending Community College, MDRC.

Crissey, Sarah R. (2009). “Educational Attainment in the United States: 2007," Current Population Reports. P20-560. U.S. Census Bureau.

Dynarski, Susan (2000). "Hope for Whom? Financial Aid for the Middle Class and Its Impact on College Attendance.” National Tax Journal 53:3, 629-661.

Dynarski, Susan (2003). "Does Aid Matter? Measuring the Effect of Student Aid on College Attendance and Completion.” American Economic Review 93:1, 279-288.

Dynarski, Susan (2008). "Building the Stock of College-Educated Labor." Journal of Human Resources 43:3, 576-610. 
Fryer, Roland G., Jr. (2010). "Financial Incentives and Student Achievement: Evidence from Randomized Trials,” NBER Working Paper No. 15898.

Jackson, C. Kirabo (2010a). “A Little Now for a Lot Later: A Look at a Texas Advanced Placement Incentive Program” forthcoming in Journal of Human Resources 45:3.

Jackson, C. Kirabo (2010b). “A Stitch in Time: The Effects of a Novel Incentive-Based HighSchool Intervention on College Outcomes,” NBER Working Paper No. 15722.

Jacobson, Louis, Robert LaLonde, and Daniel G. Sullivan (2005). "Estimating the returns to community college schooling for displaced workers.” Journal of Econometrics 125, 271304.

Jacobson, Louis and Christine Mokher (2009). Pathways to Boosting the Earnings of LowIncome Students by Increasing Their Educational Attainment. Prepared for the Bill \& Melinda Gates Foundation by the Hudson Institute Center for Employment Policy and CNA Analysis \& Solutions, January 2009.

Kane, Thomas J. (1999). The Price of Admission: Rethinking How Americans Pay for College, Washington, D.C.: Brookings Institution and Russell Sage.

Lavy, Victor. (2009) "Performance Pay and Teachers’ Effort, Productivity, and Grading Ethics,” American Economic Review 99:5, 1979-2011.

Lee, David S. (2009) “Training, Wages, and Sample Selection: Estimating Sharp Bounds on Treatment Effects,” Review of Economic Studies 76:3, 1971-1102.

Milkovich, George T. and Jerry M. Newman with the assistance of Carolyn Milkovich (2002). Compensation, Boston: McGraw-Hill.

Radford, Alexandria Walton, Lutz Berkner, Sara C. Wheeless, and Bryan Shepherd (2010). Persistence and Attainment of 2003-04 Beginning Postsecondary Students: After 6 Years (NCES 2011-151). U.S. Department of Education. Washington, DC: National Center for Education Statistics. Retrieved December 7, 2010 from http://nces.ed.gov/pubsearch.

Richburg-Hayes, Lashawn, Thomas Brock, Allen LeBlanc, Christina Paxson, Cecilia Elena Rouse, and Lisa Barrow. (2009) Rewarding Persistence: Effects of a Performance-Based Scholarship Program for Low-Income Parents. New York: MDRC.

Rouse, Cecilia Elena (1994). "What to do after High School? The Two-Year versus Four-Year College Enrollment Decision,” In Ehrenberg, Ronald (Ed.), Choices and Consequences: Contemporary Policy Issues in Education, Ithaca: Cornell University Press, pp. 59-88.

Scott-Clayton, Judith (2009). “On Money and Motivation: A Quasi-Experimental Analysis of Financial Incentives for College Achievement.” Columbia Teachers College mimeo. 
Stinebrickner, Ralph and Todd R. Stinebrickner. (2003) "Working during School and Academic Performance,” Journal of Labor Economics 21(2): 473-491.

Stinebrickner, Ralph and Todd R. Stinebrickner. (2009) “Learning about Academic Ability and the College Drop-out Decision,” NBER Working Paper No. 14810.

Trachter, Nicholas. (2009) "Ladders in Post-Secondary Education: Academic 2-year Colleges as a Stepping Stone,” University of Chicago mimeo.

Westfall, Peter H. and S. Stanley Young. 1993. Resampling-based Multiple Testing. New York, NY: John Wiley \& Sons, Inc. 


\section{Appendix A}

We follow Jacobson and Mokher (2009) and classify courses into eight broad categories—Health Related; Humanities; Professional; Science, Technology, Engineering, and Mathematics (STEM); Social Sciences; Vocational/Technical; Remedial; and Other. All courses are categorized based on their "discipline" code which loosely corresponds to an academic department rather than categorizing classes based on the course title itself.

In Table A we list each course prefix and the associated department, academic area, or program description by the field in which we categorized them. In a few cases we had to use information about individual course descriptions, course catalogs, syllabi, and/or online college brochures in order to make a decision on field categorization. As described more fully below, DSPE courses are placed in the Health Related field; HNRS courses are placed in the Humanities field; CISX and ENSC courses were placed in the STEM field; ELAP, ETRN, IDEL, and PWEL courses were placed in the Vocational/Technical field, and SPWF courses were placed in the “Other” field category.

Courses at DCC in the "Direct Support Professional" program, prefix DSPE, are placed in the Health Related field because they are in the Allied Health Division at the City Park Campus. The "Honors" courses at Delgado Community College—-those with the prefix HNRS— were placed in the "Humanities" field based on course titles and descriptions in the 2005-06 catalog. Two of the course titles were Literature and Medicine and Activism and Change. Modernism in the Arts (HUMA 220) is listed under the honors section of the 2005-06 catalog so we assume that this is the same course as HNRS 220. 
An online brochure from LTC describes CISX 1000 as an introduction to information systems so the CISX courses were placed in the STEM field. At other colleges ENSC courses are in environmental science so we assume that this is true at LTC as well, and these courses are also placed in STEM. An online syllabus from LTC describes ELAP 1400 as "basic electricity marine application" so we place the ELAP courses in the Vocational/Technical field. Online brochures from LTC describe ETRN courses as having to do with alternating and direct current circuits and IDEL courses as electronics electives so courses with both prefixes are placed in the Vocational/Technical field. Finally, an online LTC syllabus describes PWEL 1130 as Training and Testing Pipe GTAW (Cu.Ni) so courses with the PWEL prefix are also placed in the Vocational/Technical field.

We were unable to decipher what program is described by the SPWF prefix so these few courses at DCC were placed in the Other category. 
Appendix Table A: Course Field Categorization

\begin{tabular}{|c|c|}
\hline Course Prefix by Field & Department, Academic Area, or Program Description \\
\hline \multicolumn{2}{|l|}{ Health Related } \\
\hline DIET & Dietetic Technician \\
\hline DMTP & Dietary Manager \\
\hline DSPE & Direct Support Professional ${ }^{1}$ \\
\hline EMTE & Emergency Medical Technician-Paramedic \\
\hline HEIT & Health Information Technology \\
\hline HESC & Health Sciences \\
\hline HMDT & Medical Terminology \\
\hline HNUR & Nursing Fundamentals \\
\hline MLTS & Medical Laboratory Technician \\
\hline MSTH & Massage Therapy \\
\hline NURS & Nursing \\
\hline OPHT & Ophthalmic Assistant \\
\hline PHAR & Pharmacy Technician \\
\hline PRNU & Practical Nursing \\
\hline RCPS & Respiratory Therapist \\
\hline RSPT & Respiratory Care Technology \\
\hline SURG & Surgical Technology \\
\hline WELL & Wellness \\
\hline \multicolumn{2}{|l|}{ Humanities } \\
\hline ASLS & American Sign Language Studies \\
\hline ENGL & English \\
\hline ENRE & English/Reading \\
\hline ESLN & English as a Second Language \\
\hline FNAR & Fine Arts \\
\hline FREN & French \\
\hline HIST & History \\
\hline HNRS & Honors $^{2}$ \\
\hline HUMA & Humanities \\
\hline MUSB & Music Business \\
\hline MUSC & Music \\
\hline PHIL & Philosophy \\
\hline SPAH & Special Topics in Arts and Humanities \\
\hline SPAN & Spanish \\
\hline THEA & Theatre Arts \\
\hline VISC & Visual Communications (Commercial Art) \\
\hline Other & \\
\hline
\end{tabular}




$\begin{array}{ll}\text { ADOT } & \text { Administrative Office Technology } \\ \text { CCSS } & \text { College Success Skills } \\ \text { CULA } & \text { Culinary Arts } \\ \text { HORT } & \text { Horticulture } \\ \text { INTD } & \text { Interior Design } \\ \text { JOBS } & \text { Job Seeking Skills } \\ \text { KYBD } & \text { Keyboarding } \\ \text { MSCM } & \text { Mass Communication } \\ \text { ORNT } & \text { Freshman Orientation } \\ \text { PHYE } & \text { Physical Education } \\ \text { SFTY } & \text { Safety } \\ \text { SPCA } & \text { Special Topics in Communication } \\ \text { SPCH } & \text { Speech/Oral Communication } \\ \text { SPWF } & \text { Unknown } \\ \text { Professional } & \\ \text { ACCT } & \text { Accounting } \\ \text { ARCH } & \text { Architectural/Design Construction Technology } \\ \text { BUSG } & \text { Business Studies/General } \\ \text { BUSL } & \text { Business Law } \\ \text { CADD } & \text { Computer Aided Design and Drafting } \\ \text { CRJU } & \text { Criminal Justice } \\ \text { HOST } & \text { Hospitality } \\ \text { MANG } & \text { Management } \\ \text { MARK } & \text { Marketing } \\ \text { OSYS } & \text { Office Systems } \\ \text { RLST } & \text { Real Estate } \\ \text { Remedial } & \\ \text { DVEN } & \text { Developmental English } \\ \text { DVMA } & \text { Developmental Math } \\ \text { DVRE } & \text { Developmental Reading } \\ \text { READ } & \text { Reading } \\ \text { WKEY } & \text { Skills Improvement } \\ \text { Social Sciences } & \text { Pociology } \\ \text { ANTH } & \text { Anthropology and Geography } \\ \text { ECED } & \text { Early Childhood Education } \\ \text { ECON } & \text { Economics } \\ \text { EDUC } & \text { Education } \\ \text { POLI } & \text { Political Science } \\ \text { PSYC } & \text { SoCI } \\ \text { Science, Technology , Engineering and Mathematics (STEM) } \\ & \end{array}$




\begin{tabular}{ll} 
BIOL & Biology \\
CHEM & Chemistry \\
CISX & Computer Information Systems \\
CMIN & Computer Information Technology \\
CNET & Computer Network Technology \\
CPTR & Computers \\
ENSC & Environmental Sciences \\
GEOL & Geology \\
HBIO & Microbiology \\
MATH & Mathematics \\
PHYS & Physics \\
SCIE & Science \\
Vocational/Technical & \\
BLDG & Building Technology Specialist \\
CARP & Carpentry \\
COOP & Cooperative Education \\
ELAP & Electricity \\
ELCT & Electrical Technology \\
ELEC & Electrician \\
ELET & Electrical-Electronics Engineering Technology \\
ELST & Electronics Servicing Technology \\
ETRN & Electrical Circuits \\
IDEL & Technology-General \\
MOVH & Welding \\
PWEL & Motor Vehicle Technology \\
TECH & \\
TEVP & Plumbing \\
WELD & \\
\hline
\end{tabular}

Notes: ${ }^{1}$ Courses are in the Allied Health Division at the City Park Campus. ${ }^{2}$ All course titles under HNRS seem to be Humanities courses. See Appendix text for more detail. ${ }^{3}$ We were unable to decipher the field for SPWF and so include it in the "Other" category. ${ }^{4}$ An online brochure from LTC describes CISX 1000 as introduction to information systems. ${ }^{5}$ At other colleges ENSC courses are in environmental science. ${ }^{6}$ An online syllabus from LTC describes ELAP 1400 as basic electricity marine application. ${ }^{7}$ An online brochure from LTC describes ETRN courses as having to do with alternating and direct current circuits. ${ }^{8}$ An online brochure from LTC describes IDEL 2995 as Special Projects III. Other IDEL courses are Electronics Electives. ${ }^{9}$ An online LTC syllabus describes PWEL 1130 as Training and Testing Pipe GTAW (Cu.Ni). 
Figure 1a: First Semester Course Grade Distribution by Treatment Status

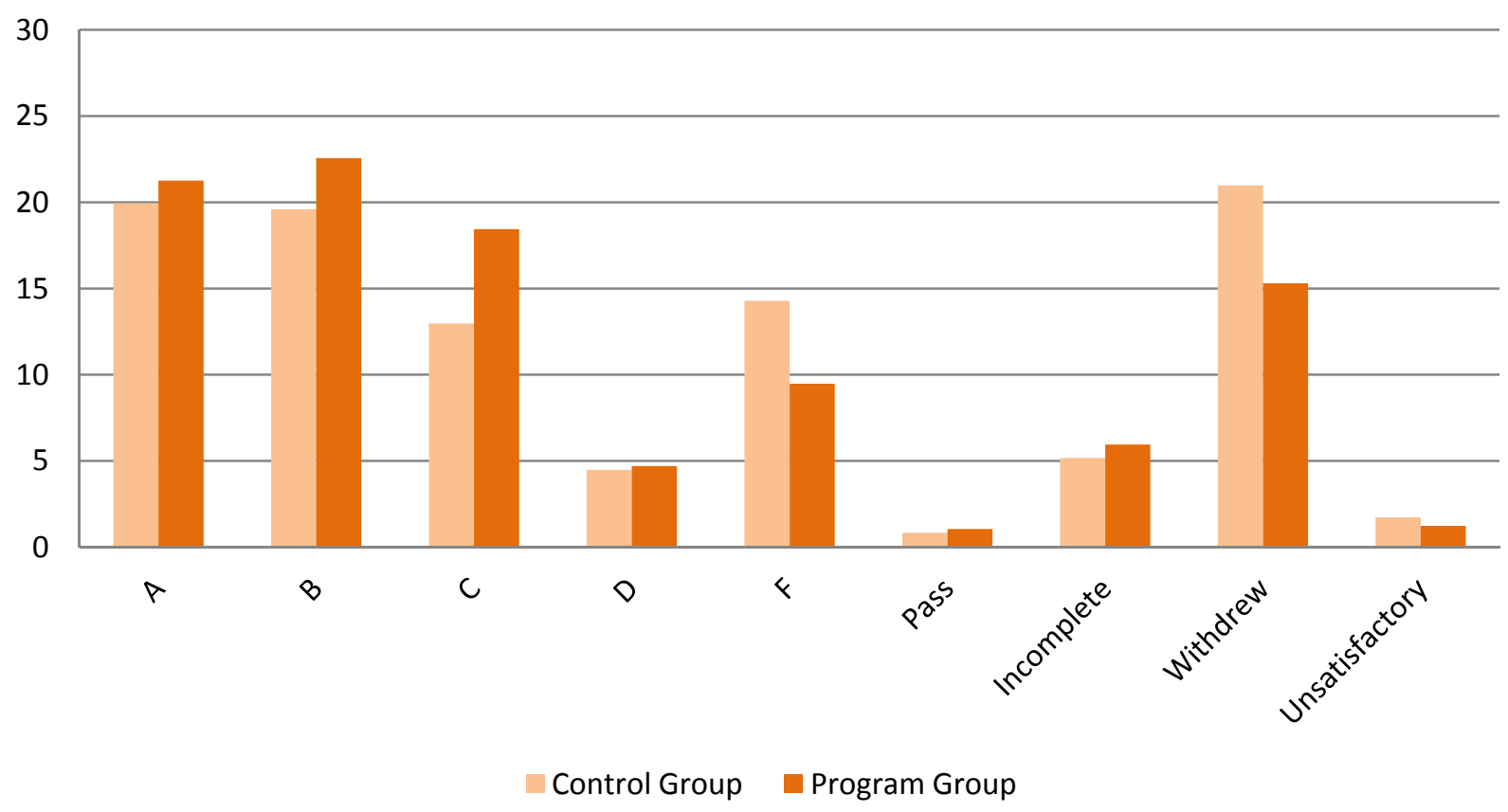

Figure 1b: Second Semester Course Grade Distribution by Treatment Status

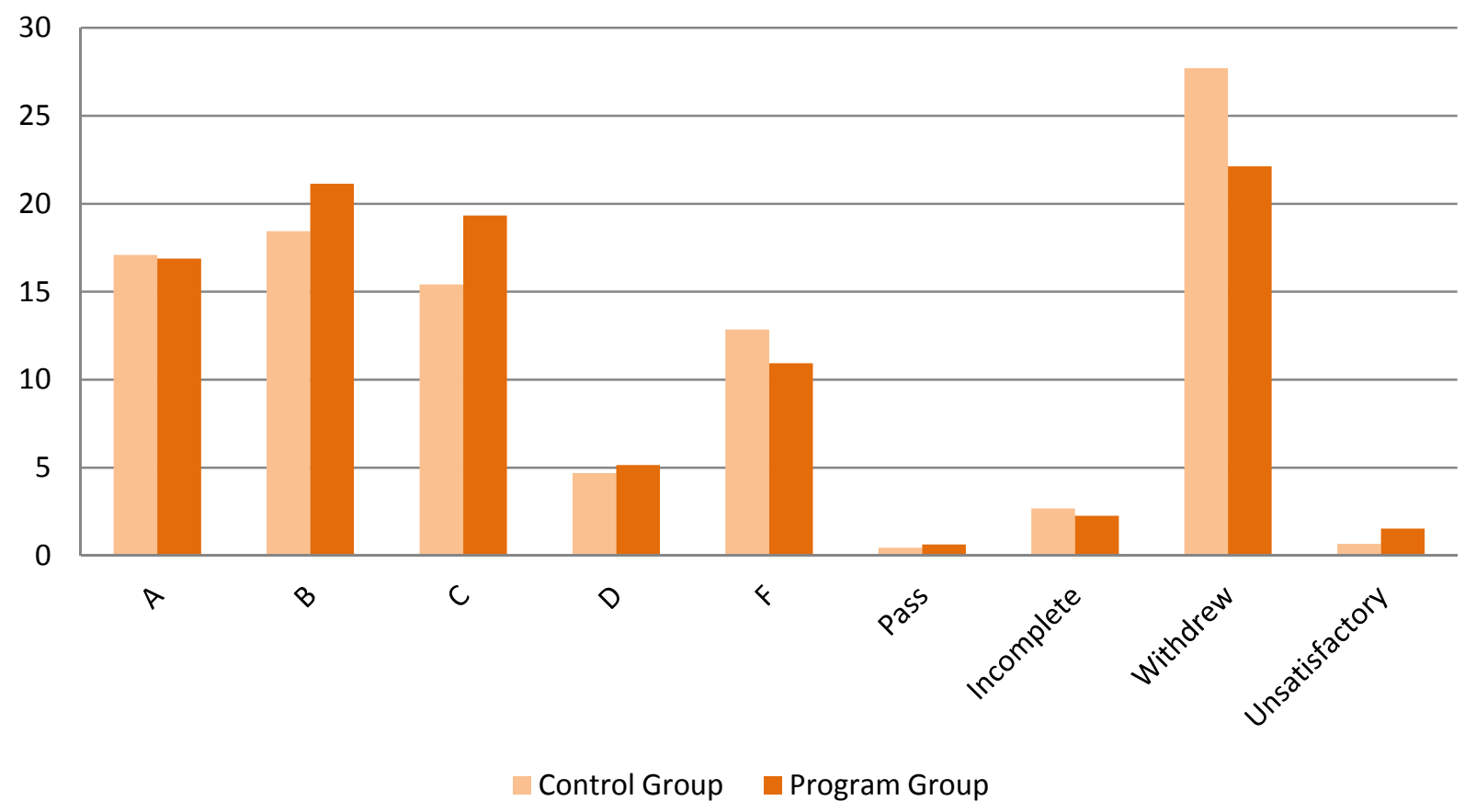


Table 1: Total Sample Size by Campus and Cohort

\begin{tabular}{|c|c|c|c|c|}
\hline Cohort & $\begin{array}{l}\text { Delgado CC } \\
\text {-- City Park }\end{array}$ & $\begin{array}{c}\text { Delgado CC } \\
\text {-- West } \\
\text { Bank } \\
\end{array}$ & $\begin{array}{l}\text { Louisiana } \\
\text { Technical } \\
\text { College }\end{array}$ & Total \\
\hline Spring 2004 & 172 & 45 & 72 & 289 \\
\hline Summer 2004 & 133 & 72 & 43 & 248 \\
\hline Fall 2004 & 246 & 91 & 48 & 385 \\
\hline Spring 2005 & 58 & 0 & 39 & 97 \\
\hline All cohorts & 609 & 208 & 202 & 1019 \\
\hline
\end{tabular}


Table 2: Scholarship Payment by Random Assignment

\begin{tabular}{|c|c|c|}
\hline & \multicolumn{2}{|c|}{ Random Assignment } \\
\hline & Program Group & Control Group \\
\hline \multicolumn{3}{|l|}{ First semester } \\
\hline Number of students receiving 1 or more payment & 424 & 2 \\
\hline Percent of students receiving 1 or more payment & 84.0 & 0.4 \\
\hline Percent received \$250 (among recipients) & 22.4 & 50.0 \\
\hline Percent received $\$ 500$ (among recipients) & 15.1 & 0.0 \\
\hline Percent received $\$ 1000$ (among recipients) & 60.6 & 50.0 \\
\hline Total dollars received (among recipients) & 751.8 & 625.0 \\
\hline \multicolumn{3}{|l|}{ Second semester } \\
\hline Number of students receiving 1 or more payment & 314 & 1 \\
\hline Percent of students receiving 1 or more payment & 62.2 & 0.2 \\
\hline Percent received \$250 (among recipients) & 23.9 & 100.0 \\
\hline Percent received $\$ 500$ (among recipients) & 14.6 & 0.0 \\
\hline Percent received $\$ 1000$ (among recipients) & 58.3 & 0.0 \\
\hline Total dollars received (among recipients) & 736.1 & 250.0 \\
\hline \multicolumn{3}{|l|}{ Cumulative, 1-7 semesters after random assignment } \\
\hline Percent of students receiving 1 or more payment & 89.7 & 0.4 \\
\hline Percent ever receiving $\$ 1000$ scholarship & 59.4 & 0.2 \\
\hline Percent receiving full $\$ 2000$ scholarship & 30.5 & 0.0 \\
\hline Total dollar value of payments received & 1132.9 & 2.9 \\
\hline
\end{tabular}

Notes: Distribution of payments among recipients may not sum to 100 because a few received payments of other sizes. 
Table 3: Characteristics of Opening Doors Louisiana Participants and Beginning Postsecondary Survey (BPS) Students

\begin{tabular}{|c|c|c|c|}
\hline \multirow[b]{2}{*}{ Characteristics } & \multirow[b]{2}{*}{$\begin{array}{l}\text { Opening Doors } \\
\text { Louisiana Study }\end{array}$} & \multicolumn{2}{|c|}{ BPS } \\
\hline & & $\begin{array}{c}\text { 2-Year Public } \\
\text { College } \\
\text { Students }\end{array}$ & $\begin{array}{l}\text { Louisiana sub- } \\
\text { sample }\end{array}$ \\
\hline & $(1)$ & (2) & (3) \\
\hline Age (years) & 25.293 & 20.591 & 20.947 \\
\hline Share age $17-18$ & 0.041 & 0.391 & 0.183 \\
\hline Share age $19-20$ & 0.138 & 0.334 & 0.499 \\
\hline Share age $21-35$ & 0.819 & 0.276 & 0.318 \\
\hline Female & 0.924 & 0.542 & 0.568 \\
\hline \multicolumn{4}{|l|}{ Race/ethnicity shares } \\
\hline Hispanic & 0.026 & 0.157 & 0.097 \\
\hline Black & 0.849 & 0.137 & 0.432 \\
\hline Asian & 0.004 & 0.047 & 0.067 \\
\hline American Indian & 0.005 & 0.007 & 0.000 \\
\hline Other (non white) & 0.004 & 0.045 & 0.044 \\
\hline \multicolumn{4}{|l|}{ Children } \\
\hline Has any children & 1 & 0.155 & 0.222 \\
\hline Has child under 6 (conditional on any) & 0.806 & 0.714 & 0.623 \\
\hline Number of children (conditional on any) & 1.813 & 1.919 & 1.607 \\
\hline Average household size & 3.655 & 3.690 & 3.927 \\
\hline Financially dependent on parents & 0.172 & 0.727 & 0.732 \\
\hline \multicolumn{4}{|l|}{ Education } \\
\hline Highest grade completed (years) & 11.714 & & \\
\hline Years since high school & 6.598 & 2.065 & 2.181 \\
\hline Completed any college courses & 0.337 & 0.149 & 0.069 \\
\hline Enrolled to complete certificate program & 0.135 & 0.134 & 0.215 \\
\hline Enrolled to transfer to 4 year college & 0.155 & 0.420 & 0.245 \\
\hline \multicolumn{4}{|l|}{ Highest degree completed } \\
\hline GED & 0.169 & 0.082 & 0.083 \\
\hline High school diploma & 0.697 & 0.867 & 0.903 \\
\hline Technical certificate, associate's degree & & & \\
\hline or higher & 0.103 & 0.006 & 0.023 \\
\hline First member of family to attend college & 0.426 & 0.322 & 0.277 \\
\hline US citizen & 0.990 & 0.925 & 0.986 \\
\hline Number of Observations & 1019 & 5680 & 70 \\
\hline
\end{tabular}


Notes: Based on authors' calculations from MDRC data and data from the U.S. Department of Education's 2004 Beginning Postsecondary Survey (BPS). We limit the BPS data to first-time students between the ages of 17 and 34 at two-year public colleges in column (2) and to the subset of firsttime, two-year public college students in Louisiana in column (3). BPS means are weighted by the 2004 study weight. Sample sizes for the BPS have been rounded to the nearest 10 . 
Table 4: Randomization of Program and Control Groups

\begin{tabular}{|c|c|c|c|c|}
\hline \multirow[b]{2}{*}{ Baseline characteristic } & \multicolumn{2}{|c|}{ Random assignment } & \multirow[b]{2}{*}{$\begin{array}{l}\mathrm{p} \text {-value of } \\
\text { difference }\end{array}$} & \multirow[b]{2}{*}{$\mathrm{N}$} \\
\hline & $\begin{array}{l}\text { Program } \\
\text { Group }\end{array}$ & $\begin{array}{l}\text { Control } \\
\text { Group }\end{array}$ & & \\
\hline Female $\%$ & 91.0 & 93.8 & 0.09 & 1019 \\
\hline Age (years) & 25.2 & 25.3 & 0.69 & 1019 \\
\hline \multicolumn{5}{|l|}{ Marital status \% } \\
\hline Married, living w/ spouse & 8.8 & 7.6 & 0.47 & 1003 \\
\hline Married, not living w/ spouse & 11.0 & 10.5 & 0.81 & 1003 \\
\hline Unmarried, living w/ partner & 5.2 & 7.5 & 0.14 & 1003 \\
\hline Unmarried, not living w/ partner & 75.0 & 74.4 & 0.83 & 1003 \\
\hline \multicolumn{5}{|l|}{ Race/ethnicity ${ }^{\mathrm{a}} \%$} \\
\hline Hispanic & 3.0 & 2.2 & 0.44 & 985 \\
\hline Black & 86.9 & 82.8 & 0.07 & 985 \\
\hline White & 8.6 & 12.3 & 0.06 & 985 \\
\hline Asian & 0.2 & 0.6 & 0.31 & 985 \\
\hline Multi-racial & 0.8 & 0.6 & 0.70 & 985 \\
\hline Other & 0.0 & 0.8 & 0.05 & 985 \\
\hline Number of children & 1.8 & 1.9 & 0.21 & 1014 \\
\hline Age of youngest child (years) & 3.1 & 3.2 & 0.66 & 1000 \\
\hline Receiving any government benefit \% & 72.4 & 69.5 & 0.31 & 1015 \\
\hline Unemployment insurance & 5.1 & 3.8 & 0.32 & 996 \\
\hline Household receiving SSI & 14.2 & 12.2 & 0.35 & 996 \\
\hline Household receiving TANF & 10.5 & 10.1 & 0.84 & 996 \\
\hline Household receiving food stamps & 61.7 & 62.0 & 0.94 & 996 \\
\hline Public housing or section 8 housing & 15.3 & 20.6 & 0.04 & 901 \\
\hline Financially dependent on parents \% & 17.6 & 16.8 & 0.71 & 1006 \\
\hline Ever employed \% & 98.0 & 97.5 & 0.56 & 1014 \\
\hline Currently employed \% & 51.0 & 52.2 & 0.70 & 1017 \\
\hline Earned HS diploma \% & 70.7 & 68.7 & 0.49 & 1016 \\
\hline Earned GED \% & 15.2 & 18.6 & 0.15 & 1016 \\
\hline Earned tech certificate \% & 10.7 & 10.0 & 0.69 & 1016 \\
\hline \multicolumn{5}{|l|}{ Main reason for enrolling in college ${ }^{b} \%$} \\
\hline Complete certificate program & 12.7 & 14.4 & 0.43 & 1005 \\
\hline Obtain AA & 57.5 & 55.1 & 0.43 & 1005 \\
\hline Transfer to 4-yr college & 15.9 & 15.2 & 0.76 & 1005 \\
\hline Obtain job skills & 12.3 & 14.3 & 0.34 & 1005 \\
\hline Other reason & 6.1 & 6.1 & 1.00 & 1005 \\
\hline Completed any college courses before RA \% & 32.8 & 34.6 & 0.54 & 993 \\
\hline First family member to attend college $\%$ & 42.8 & 42.5 & 0.93 & 976 \\
\hline
\end{tabular}


Notes: All means are adjusted for campus interacted with cohort. ${ }^{a}$ Hispanic and race categories are mutually exclusive. ${ }^{b}$ Categories are not mutually exclusive. 
Table 5: Educational Outcomes Based on Transcript Data: All Cohorts

\begin{tabular}{|c|c|c|c|}
\hline & $\begin{array}{c}\text { Control Group } \\
\text { Mean }\end{array}$ & $\begin{array}{c}\text { Program } \\
\text { Effects }\end{array}$ & $\begin{array}{c}\text { P-values } \\
\text { adjusted for } \\
\text { multiple testing }\end{array}$ \\
\hline & $(1)$ & $(2)$ & (3) \\
\hline \multicolumn{4}{|c|}{ First semester after random assignment } \\
\hline \multirow[t]{2}{*}{ Enrolled in any course (\%) } & 76.654 & 5.346 & 0.070 \\
\hline & & $(2.294)$ & \\
\hline \multirow[t]{2}{*}{ Total credits attempted } & 7.99 & 0.557 & 0.129 \\
\hline & & $(0.279)$ & \\
\hline \multirow[t]{2}{*}{ Regular credits attempted } & 5.101 & 0.497 & 0.129 \\
\hline & & $(0.254)$ & \\
\hline \multirow[t]{2}{*}{ Total credits earned } & 4.609 & 1.222 & $<0.0001$ \\
\hline & & $(0.285)$ & \\
\hline \multirow[t]{2}{*}{ Regular credits earned } & 3.113 & 0.934 & 0.001 \\
\hline & & $(0.242)$ & \\
\hline \multicolumn{4}{|c|}{ Second semester after random assignment } \\
\hline \multirow[t]{2}{*}{ Enrolled in any course (\%) } & 49.611 & 14.956 & $<0.0001$ \\
\hline & & $(2.849)$ & \\
\hline \multirow[t]{2}{*}{ Total credits attempted } & 4.93 & 1.234 & 0.0001 \\
\hline & & $(0.300)$ & \\
\hline \multirow[t]{2}{*}{ Regular credits attempted } & 3.547 & 0.913 & 0.001 \\
\hline & & $(0.258)$ & \\
\hline \multirow[t]{2}{*}{ Total credits earned } & 2.77 & 1.126 & $<0.0001$ \\
\hline & & $(0.265)$ & \\
\hline \multirow[t]{2}{*}{ Regular credits earned } & 2.111 & 0.854 & 0.001 \\
\hline & & $(0.232)$ & \\
\hline
\end{tabular}

Notes: Each estimate comes from a separate regression. Standard errors are in parentheses. Sample size is 1019. All outcome characteristics are based on transcript data from the intervention campuses. Each regression also includes controls for the randomization pool. P-values are adjusted using bootstrap resampling with the stepdown approach. We consider the full set of outcomes in this table within semester in making the adjustments as well as the part-time and full-time enrollment indicators discussed in the text. 
Table 6: Longer Run Outcomes and Effects on Enrollment at "All" Institutions: First Two Cohorts

\begin{tabular}{|c|c|c|c|c|}
\hline & $\begin{array}{l}\text { Transcript Data } \\
\text { All Students }\end{array}$ & $\begin{array}{c}\text { Transcript + } \\
\text { Clearinghouse } \\
\text { Data All } \\
\text { Students }\end{array}$ & $\begin{array}{c}\text { Transcript } \\
\text { Data Delgado } \\
\text { only }\end{array}$ & $\begin{array}{c}\text { Clearinghouse } \\
\text { Data Delgado } \\
\text { Only }\end{array}$ \\
\hline & $(1)$ & $(2)$ & $(3)$ & $(4)$ \\
\hline \multicolumn{5}{|l|}{ Semesters enrolled in school } \\
\hline Registered for any course in $1^{\text {st }}$ & 4.681 & 5.062 & 5.662 & 5.662 \\
\hline \multirow[t]{2}{*}{ semester } & $(3.470)$ & (3.459) & (3.755) & $(3.755)$ \\
\hline & [0.172] & [0.149] & {$[0.154]$} & [0.154] \\
\hline \multirow{3}{*}{$\begin{array}{l}\text { Registered for any course in } \\
\text { 2nd semester }\end{array}$} & 18.142 & 17.553 & 19.229 & 18.798 \\
\hline & (3.997) & $(4.000)$ & $(4.636)$ & $(4.593)$ \\
\hline & {$[<0.0001]$} & {$[<0.0001]$} & {$[0.0004]$} & {$[0.0004]$} \\
\hline \multirow{3}{*}{$\begin{array}{l}\text { Registered for any course in } \\
\text { 3rd semester }\end{array}$} & 11.789 & 12.420 & 14.685 & 15.213 \\
\hline & $(4.041)$ & $(4.140)$ & $(4.815)$ & $(4.793)$ \\
\hline & {$[0.008]$} & [0.007] & {$[0.005]$} & {$[0.004]$} \\
\hline \multirow{3}{*}{$\begin{array}{l}\text { Number of semesters enrolled } \\
\text { in any course in 1st year }\end{array}$} & 0.346 & 0.350 & 0.396 & 0.397 \\
\hline & $(0.088)$ & $(0.088)$ & $(0.102)$ & $(0.101)$ \\
\hline & {$[0.001]$} & {$[0.001]$} & {$[0.0006]$} & {$[0.0006]$} \\
\hline \multirow{3}{*}{$\begin{array}{l}\text { Number of semesters enrolled } \\
\text { in any course in second year }\end{array}$} & 0.125 & 0.120 & 0.151 & 0.120 \\
\hline & $(0.065)$ & $(0.075)$ & $(0.076)$ & $(0.080)$ \\
\hline & [0.234] & {$[0.400]$} & [0.223] & [0.459] \\
\hline \multirow{3}{*}{$\begin{array}{l}\text { Number of semesters enrolled } \\
\text { in any course over first } 2 \text { years }\end{array}$} & 0.471 & 0.471 & 0.547 & 0.517 \\
\hline & (0.129) & $(0.137)$ & (0.149) & $(0.150)$ \\
\hline & [0.003] & {$[0.005]$} & {$[0.005]$} & {$[0.005]$} \\
\hline \multicolumn{5}{|l|}{$\begin{array}{l}\text { Total credits earned } \\
\text { Total credits earned in first }\end{array}$} \\
\hline \multirow[t]{3}{*}{ year } & 3.345 & & 4.016 & \\
\hline & $(0.849)$ & & $(0.977)$ & \\
\hline & {$[0.001]$} & & {$[0.0004]$} & \\
\hline \multicolumn{5}{|l|}{ Total credits earned in second } \\
\hline \multirow[t]{3}{*}{ year } & 0.343 & & 0.402 & \\
\hline & $(0.456)$ & & $(0.485)$ & \\
\hline & {$[0.676]$} & & {$[0.747]$} & \\
\hline \multicolumn{5}{|l|}{ Total credits earned over first 2} \\
\hline \multirow[t]{3}{*}{ years } & 3.688 & & 4.417 & \\
\hline & $(1.180)$ & & $(1.313)$ & \\
\hline & [0.013] & & {$[0.006]$} & \\
\hline Number of observations & 537 & 537 & 422 & 422 \\
\hline
\end{tabular}


Notes: Each estimate comes from a separate regression. Standard errors are in parentheses; $p$-values adjusted for multiple testing are shown in brackets. Estimates shown in columns (1) and (2) limit the sample to the first two study cohorts. Estimates show in columns (3) and (4) limit the sample to the first two cohorts of students at Delgado only. Cumulative outcomes for the first and second years reflect three semesters of potential enrollment. Cumulative outcomes over the first two years reflect six semesters of potential enrollment. We adjust $p$-values considering outcomes shown in this table, registration in semester 4 , registration in semester 5 , and registration in semester 6 , within year and sample. For purposed of adjusting $p$-values, we include outcomes reflecting cumulative measures over the first two years with second year outcomes. 
Table 7. Credits Attempted and Earned by Course Subject Field: All Cohorts

\begin{tabular}{|c|c|c|c|c|}
\hline & \multicolumn{2}{|c|}{ Credits Attempted } & \multicolumn{2}{|c|}{ Credits Earned } \\
\hline & $\begin{array}{c}\text { Control } \\
\text { Group Mean }\end{array}$ & $\begin{array}{c}\text { Program } \\
\text { Effect } \\
\text { Estimates }\end{array}$ & $\begin{array}{c}\text { Control } \\
\text { Group Mean }\end{array}$ & $\begin{array}{c}\text { Program } \\
\text { Effect } \\
\text { Estimates }\end{array}$ \\
\hline & (1) & (2) & (3) & (4) \\
\hline $\begin{array}{l}\text { First and second semesters after } \\
\text { random assignment }\end{array}$ & & & & \\
\hline Health Related & 1.587 & $\begin{array}{c}0.063 \\
(0.262) \\
{[0.809]}\end{array}$ & 1.012 & $\begin{array}{c}0.146 \\
(0.231) \\
{[0.768]}\end{array}$ \\
\hline Humanities & 3.101 & $\begin{array}{c}0.159 \\
(0.179) \\
{[0.768]}\end{array}$ & 1.673 & $\begin{array}{c}0.372 \\
(0.167) \\
{[0.246]}\end{array}$ \\
\hline Professional & 0.507 & $\begin{array}{c}0.133 \\
(0.124) \\
{[0.768]}\end{array}$ & 0.314 & $\begin{array}{c}0.143 \\
(0.103) \\
{[0.586]}\end{array}$ \\
\hline $\begin{array}{l}\text { Science, Technology, Engineering, } \\
\text { \& Mathematics (STEM) }\end{array}$ & 4.173 & $\begin{array}{c}0.354 \\
(0.225) \\
{[0.553]}\end{array}$ & 2.384 & $\begin{array}{c}0.654 \\
(0.204) \\
{[0.019]}\end{array}$ \\
\hline Social Sciences & 0.760 & $\begin{array}{c}0.411 \\
(0.118) \\
{[0.008]}\end{array}$ & 0.503 & $\begin{array}{c}0.412 \\
(0.107) \\
{[0.002]}\end{array}$ \\
\hline Vocational/Technical & 0.218 & $\begin{array}{c}0.255 \\
(0.140) \\
{[0.456]}\end{array}$ & 0.164 & $\begin{array}{c}0.240 \\
(0.129) \\
{[0.441]}\end{array}$ \\
\hline Remedial & 1.156 & $\begin{array}{c}0.156 \\
(0.153) \\
{[0.768]}\end{array}$ & 0.425 & $\begin{array}{c}0.143 \\
(0.079) \\
{[0.456]}\end{array}$ \\
\hline Other & 1.400 & $\begin{array}{c}0.204 \\
(0.129) \\
{[0.553]}\end{array}$ & 0.897 & $\begin{array}{c}0.196 \\
(0.106) \\
{[0.456]}\end{array}$ \\
\hline
\end{tabular}

Notes: Each cell represents an estimate from a separate regression and comes from a regression that includes indicators for randomization pool but no other baseline characteristics. See text and Appendix A for course subject field descriptions. Standard errors are in parentheses; $p$-values adjusted for multiple testing are shown in brackets. There are 1010 observations used in each regression. All outcomes shown plus the aggregate "easy" and "hard" course credit variables discussed in the text are taken into account when adjusting the $p$-values for multiple testing. 
Table 8: Effects on Achievement and Effort with Lee Bounds

\begin{tabular}{lcccc}
\hline & $\begin{array}{c}\text { Control } \\
\text { Mean }\end{array}$ & $\begin{array}{c}\text { Treatment } \\
\text { Impact }\end{array}$ & $\begin{array}{c}\text { Lower } \\
\text { Bound }\end{array}$ & $\begin{array}{c}\text { Upper } \\
\text { Bound }\end{array}$ \\
\hline & $(1)$ & $(2)$ & $(3)$ & $(4)$ \\
\cline { 2 - 5 } Term GPA 1st semester after RA & 2.203 & 0.182 & 0.040 & 0.381 \\
& & $(0.085)$ & $(0.107)$ & $(0.109)$ \\
Term GPA 2nd semester after RA & 2.171 & 0.068 & -0.225 & 0.361 \\
Hours per week spent: & & $(0.104)$ & $(0.147)$ & $(0.152)$ \\
On campus 1st semester & & & & \\
& 11.980 & 0.066 & -0.148 & 0.437 \\
Studying 1st semester & & $(0.321)$ & $(0.387)$ & $(0.478)$ \\
& \multirow{2}{*}{0.847} & 0.119 & -0.578 & 0.639 \\
On campus 2nd semester & & $(0.457)$ & $(0.677)$ & $(0.576)$ \\
& 6.129 & 0.476 & -0.042 & 1.472 \\
Studying 2nd semester & & $(0.390)$ & $(0.541)$ & $(0.588)$ \\
& 4.470 & 0.684 & -0.458 & 1.758 \\
& & $(0.519)$ & $(0.808)$ & $(0.713)$ \\
\hline
\end{tabular}

Notes: Each row represents an estimate from a separate regression. Standard errors are in parentheses. Outcome measures are based on transcript data and survey responses to the MDRC follow-up survey. Categorical responses on hours per week are converted to a continuous measure by assigning the midpoint of the category. Upper and lower bound estimates and standard errors are calculated following Lee (2009). Data are trimmed at the randomization pool level. Estimates shown represent the average of these estimates weighted by observation shares. Overall there are 739 GPA observations for semester 1 and 517 GPA observations for semester 2. Hours per week spent on campus is available for 635 observations in the 1 st semester and 460 observations in the 2 nd semester. Hours spent studying is available for 637 observations in the 1st semester and 214 observations in the 2 nd semester 